\title{
Structural and semantic features of impersonal sentences (on the example of the works of A.P. Chekhov)
}

\author{
Jumaeva Feruza Ruzievna \\ Candidate of Pedagogical Sciences, Associate Professor. \\ Lecturer at the Department of Russian Language and Literature. \\ Navoi State Pedagogical Institute. Uzbekistan \\ Namazov Rustam Anvarovich \\ 1st year undergraduate student \\ 5A111301-Russian language and literature, \\ Russian language. Navoi State Pedagogical Institute. Uzbekistan
}

\begin{abstract}
The article describes the structural and semantic features of impersonal sentences on the example of the works of A.P. Chekhov. The reasons that determine the ability of the connective verb to impersonal use are investigated, a historical excursion on the impersonal use of various connective verbs is given.
\end{abstract}

Key words: impersonal offer; connective verb; semantics; compatibility.

\section{Introduction.}

Impersonal sentences are one of the most common and most diverse in terms of structure and semantics, a variety of Russian sentences. The linguistic literature constantly emphasizes the tendency of growth and ever wider dissemination of impersonal constructions in the modern Russian language. There is no consensus about the name and composition of this type of sentences, however, most researchers agree that their number and frequency of use is steadily increasing.

And yet, the role of impersonal constructions in the formation of the Russian linguistic picture of the world is very significant. The lexical content of the peculiar grammatical patterns that form impersonal constructions should be recognized as literally inexhaustible. Such templates are both specialized forms of impersonality and specialized impersonal constructions expressing the specific semantics of impersonality - a spontaneous action independent of the agent or a spontaneous state independent of the patient. The set of words capable of performing this function is growing, it expands due to the attraction of the most different parts of speech into the sphere of impersonality (up to interjections: I was oh-oh-oh). Language does not try to get rid of this way of realizing the idea of reality, but on the contrary, strengthens its position. Apparently, for the self-awareness of the bearer of Russian culture, the Russian vision of the world and, accordingly, the Russian language, it is important to cultivate and develop "impersonal" perception and reflection of being. This phenomenon requires its theoretical understanding and a detailed analysis of the linguistic material based on it.

We propose the following classification of impersonal sentences, within the framework of which we will analyze the collected material:

I. Impersonal sentences denoting natural phenomena, spontaneous actions, the state of the environment, nature, the nature of the situation;

II. Impersonal sentences denoting "the psycho-physical state of a living being"; 
III. Impersonal modal sentences;

Literature review. Discussion. IV. Quantitatively impersonal sentences.

Within each semantic-syntactic group, structural schemes of the impersonal sentences under consideration, collected by us by the method of a continuous selection of material from the works of A.P. Chekhov.

The works of A.P. We have not chosen Chekhov as a source by chance, since the works of this outstanding Russian prose writer and playwright are translated into different languages quite a lot. Chinese is no exception. Dramatic works by A.P. Chekhov are staged in theaters in China, arousing constant interest among true admirers of his talent.

Note that translations of stories and dramas by A.P. Chekhov began to appear during the life of the author himself. But the attitude of the great writer to translations of his works into various languages was ambiguous. We can say that by the end of his life V.P. Chekhov was still disappointed with any practice of translating his works, as evidenced by many of his letters. For example, a quote from his letter from 1902: "... I saw many translations from Russian - and in the end I came to the conviction that it should not be translated from Russian" (Chekhov 1982, vol. 1:15). And then, in 1903, Chekhov wrote to O. L. Knipper: "... let anyone translate, there will be no sense anyway" (Chekhov 1982, v.18: 132).

Since the leading in indefinite-personal sentences is the main member of the sentence, similar to the predicate, and it is most often expressed by a verb, we analyzed the verbs by semantics. As the basic verbs in the studied syntactic construction, the meanings of the verbs proposed in the "Explanatory Dictionary of Russian Verbs" edited by Professor L. G. Babenko were chosen. In total, 180 were selected for the study of the semantics of the verb-predicates in indefinitely personal sentences (there are 262 indefinitely personal sentences in them). Based on the available material, the following lexicosemantic groups of verbs were identified and distributed by frequency:

1) Verbs of speech activity are represented by 43 units. L.G. Babenko gives the following characteristics of this group: to pronounce, while expressing any internal emotional states; communicate, talk with each other about something, exchanging opinions, judgments, discussing common problems or condemning [Babenko, 1999, pp. 349 - 379].

The following verbs are used as predicates: speak / spoke (11), shouted / shouted (4), sentenced (2), slandered (2), called (2), invite (2), offer (2), talked, teased, whispered, dignified, hinted, persuaded, warned, and so on. Here are some examples: By two o'clock a lot had been done: two were sentenced to prison companies, one privileged person was deprived of his rights and sentenced to prison, one was acquitted, one case was postponed ("In court");

Hereinafter, we single out only the verb that belongs to this lexico-semantic group. At breakfast we started talking ("Swedish match"); After reading the letter, the doctor found it short and not cold enough.

In addition, the respect for Lyubov Fedorovna and Yusa (this is how they teased the chairman's youngest son) in a business, official letter was more than inappropriate ("Trouble");

Five days later, all the accused were again taken to court to hear the verdict. Avdeev learned that he had been sentenced to exile in the Tobolsk province ("Trouble"); The doctor was called to dinner. ("Trouble");

- What are you talking about? - Asked Solomon and looked so maliciously, as if hinted at some crime ("Steppe"); 
- ... Yesterday they were looking for them all day along the line, and in their barracks we were told that they had left for the Dymkovo area ("Lights");

"They brought the cauldrons from Nikitin," said the student, "and they ask us to accept them. And what business should we take? ("The lights"); The aunt shuddered and looked to where they were shouting ("Kashtanka");

- Ivan Osipich, here! - barked somewhere. I opened my eyes. In the next room they knocked and uncorked a bottle ("I ran into it");

- Gentlemen! I shouted in a pleading voice. - After all, this is, finally, disgusting! After all, they ask you! I am sick and I want to sleep! ("I ran into it"); Then they demanded to refresh coffee with cognac and liqueurs ("The Crow");

- Wait, Katyusha, they will invite me to the Chronicle Department to keep chronicles, then we will live differently. I'll take the number then ("The Horse and the Quivering Doe").

It can be seen from the examples given that A.P. Chekhov, using, among other things, the derivational capabilities of the Russian language, provides us with a fairly extensive synonymous series of verbs with the meaning of speech.

Thanks to this, the specificity of speech characteristic of the 19th century is visible (they dignified, conversations were conducted, etc.). Along with common words, Chekhov uses colloquial and colloquial words (slandered, barked, yelled, etc.).

2) Verbs of possession (29 units): find, receive something, acquire, borrow, achieve in various ways, become 27 the owner of something; take away secretly or forcibly; have property rights; keep intact, protect, avoiding destruction, death [Babenko, 1999, pp. 561-592].

The following verbs are used as predicates: searched / searched (7), did not find / found (7), stole (2), rob / robbed (2), fired, deprived (of rights), got used, got it, pay, gave it out, etc. ... For example: "She is glad that I hit the paramedic," the doctor thought, listening to the voice of the midwife. "After all, she lived with a paramedic like a cat with a dog, and it's a holiday for her if he is fired" ("Trouble"); - The brooch, I say, was stolen ... The lady herself ransacked everything with her own hands.

Even the doorman Mihajla was searched by themselves. Pure disgrace! Nikolai Sergeyitch only looks and clucks like a chicken. And you, young lady, tremble in vain. They didn't find anything! If you didn't take the brooch, you have nothing to fear ("Trouble"); By two o'clock a lot had been done: two were sentenced to prison companies, one privileged one was deprived of his rights and sentenced to prison, one was acquitted, one case was postponed ("In court"); Now he understood that he had been accused and taken into custody, but he was not frightened or surprised; there was such a disorder in his stomach that he was not happy with the guards ("Trouble");

- They found them on the trail of blood ... - said Panteley ("Steppe");

- ... Yesterday they were looking for them all day along the line, and in their barracks we were told that they had left for the Dymkovo area ("Lights"); - Leave it! - muttered Frolov, pulling out his wallet. - Well ... let them rob ... That's why I'm rich, to be robbed ... Without parasites ... you can't ... ("Drunk");

Pyotr Petrovich Strizhin, Colonel Ivanova's nephew, is the same one. From whom new galoshes were stolen last year, he returned from the christening at exactly two o'clock in the morning ("Negligence");

"I was, my brother, the other day I was at the races," he said, making frightened eyes. - There 
were three of us, and we took one three-ruble ticket for Shustroi in the tote. And thanks to this Nimble. We were given thirty-two rubles per ruble. I cannot, brother, without races ("Father").

This group of sentences contains verbs that convey the meaning of certain transactions with money or property: stolen (brooch, galoshes), given out (thirty-two rubles each), paid, found, robbed, etc .; court proceedings or actions of state services: deprived of rights, taken into custody, searched, etc.

3) Verbs for moving an object (26 units): move an object or object; to bring an object or its part into a state of rest - circular, oscillatory, non-translational multidirectional movement [Babenko, 1999, pp. 68-112].

The following verbs are used as predicates: submitted / served / served (9), brought / brought (4), brought (4), carried / carried (2), introduced, pulled out, drove out, sent, etc. For example: - I was worn, I signed ("Trouble"); "They brought the cauldrons from Nikitin," said the student, "and they ask us to accept them. And what business should we take? ("The lights"); Nikolashka was brought in. Nikolashka was pale and thin as a splinter. He was trembling ("Swedish match"); Served vodka and a snack ("Trouble"); When the champagne was served, we asked the provincial secretary Otyagayev, our Renan and Spinoza, to make a speech ("A story for which it is difficult to find a name"); Dinner was brought to him ("Although the meeting took place, but ..."); Brought beer ("Although the date took place, but ..."); I, your honor, was in the gymnasium, and in real, and in commercial ... Everywhere they kicked out! ("Crow"); - Another person was brought! - the policeman reports ("New Year's Great Martyrs"); - A retired military man and two officials have been brought in! - the policeman reports ... ("New Year's Great Martyrs"); - I, gentlemen, have been sent to you! They say you both got bitten by a dog! ("In Paris!"); When Madeira was drunk, they sent for cognac ("Trouble"); At six o'clock he was given the bill ("The Drunkards"); After the pork, they served him porridge with lard, then scrambled eggs with lard and fried liver, and he ate everything and admired. But what else? They also served onion pie and steamed turnips with kvass. [...] In conclusion, a large pot of honey was served ("The shoemaker and the evil spirits"). This group can be characterized as follows. First, there are words, the meaning of which conveys the features of the social structure of society in the 19th century, when servants were actively used (sent, served, brought, etc.). Secondly, let us note a group of words that directly reveals the specifics of public service (worn, introduced, brought, sent).

4) Verbs of intellectual activity (26 units): to perceive something with the help of any external senses; to understand something, penetrating into the essence of phenomena on the basis of observation and reflection, special logical inferences; give preference to someone (something); come to any conclusion, conclusion about something; mentally imagine something, assuming, guessing, perceive in thoughts, dreams, fantasies [Babenko, 1999, pp. 300-348].

The following verbs are used as predicates: looked (3), saw / saw (3), justified (2), inflated (2), would not have looked, noticed, looked at each other, looked closely, showed, saw, looked, did not understand, did not saw, thought, and so on. For example: ... If you come across such a dog in St. Petersburg or Moscow, do you know what would have happened? They wouldn't look at the law there, but instantly - don't breathe! ("Chameleon"); By two o'clock a lot had been done: two were sentenced to prison companies, one privileged one was deprived of his rights and sentenced to prison, one was acquitted, one case was postponed ("In court"); The reassured peasant did not understand that they were just as accustomed to everyday dramas and tragedies here as they were in a hospital to death, and that it was in this machine dispassion that all the horror and all the hopelessness of his situation lay ("In 
Court"); The stranger, when they saw him, turned out to be a man of about thirty, ugly and not remarkable at all ("Steppe"); In the dark they did not see his tears, and they did not accept his coat, because in the tavern there were pilgrims who did not want to see male nakedness. ("Autumn"); Mister he was rich, big, for the whole, that means, province ... Eat, drink - I don't want to! Themselves, I suppose, have seen ... ("Autumn"); Suddenly something: trrres! They thought at first that he had torn the cloth on billiards, but as they looked, my brother, he has the United States at all its seams! ("In the rooms"); - Science ... Insanity, not science ... For force they invented ... to put dust in the eyes ... ("The Thinker"); - It even seems to me that he has no talent either. So, ra ... exaggerated, exaggerated ("The Critic"). As you can see, in this group Chekhov actively uses the verbs of visual perception: they looked, saw, saw, noticed, etc. Perhaps this is due to the genre features of the story: in each small story, new characters appear, the characters and appearance of which the author learns together with the reader.

Chekhov, with the help of one verb, can convey shades of meaning, using the derivational possibilities of the verb: they looked, saw, looked, looked; thought, invented.

5) Verbs of physical impact on an object (25 units): hitting, hitting, hitting, pressing, imposing weight, force or pressing (squeezing) any object; change shape, position in space; clean, process with special tools; spoil, making it unusable; damage the body or some part of the body, cause damage, breaking, injuring, etc., cause physical suffering, take life, kill a living being (human, animal, etc.) [Babenko, 1999, p. 183- 264].

The following verbs are used as predicates: killed (5), strangled (2), knock / hit (2), released (2), hit, scratched, undressed, straightened, want to drown, cut, stole, etc. For example: - He was strangled in the bedroom, but here, fearing that he would not come to life, he was hit with something sharp ("Swedish match"); ... The piggy bank, in which the governess hid dimes and old stamps, was unlocked. They unlocked it, but failed to lock it, although they scratched the entire lock ("Trouble"); - Everyone, young lady, was searched. And they searched me all over ... They stripped us all naked and searched ... ("Trouble"); He disappeared, and two days later he showed up at the office himself, pale, tattered, with a trembling all over his body. They tied him up and put him in a cold place ("In Court"); - At night they set him right, and by morning he gave his soul to God ... the kingdom of heaven, eternal rest ... They say they captured it late ... It should be early ... ("I want to sleep"); - ... I do not need money, land, or sheep, and I do not need to be afraid of me and take off their hats when I go ("Steppe"); Kiryukha coughed, laughed and shouted as if they wanted to drown him, and Dymov chased after him and tried to grab his leg ("Steppe"); The merchants were cut so that there was no living space left on the body; finished their business and dragged both of them out of the way, father to one side, and son to the other ("Steppe"); The comedian has probably never been beaten before, because, despite his strong drunkenness, he looked at Grebeshkov with surprise and even curiosity ("The remedy for drinking binge"). The presence of verbs of this group in the prose of A.P. Chekhov (mostly verbs calling violent physical actions) speaks of the poignancy of the plot, but often the writer uses such verbs to convey the comic of the situation (see the story "The Swedish Match").

6) Verbs of a qualitative state (18 units): acquire some physical signs, become any in shape, color, structure, etc .; acquire internal qualities, properties, become any in character, inclinations, mental organization; acquire any social characteristics, become any in the perception of others, society; show any quality perceived by the senses, emit a smell, glow, etc. [Babenko, 1999, S. 480-556]. The 
following verbs are used as predicates: drown / began to drown (3), (not) insulted / insulted (4), humiliated, jinxed, feared, consoled, flatter, offended, etc. 32 For example: "Somehow... squeaks in my eyes! He thought. - We must go out into the air, otherwise I will go blind. We need to ... take a walk ... It's stuffy here. The stoves are burning everything ... Oh, o-donkeys !! Beep and the stoves are burning! Fools! " ("Although the meeting took place, but ..."); - I was insulted, humiliated ... and I insulted in my lifetime ("Champagne"); ... Your pride was offended, and now you were crying, you are going to leave, but I also have pride, and you do not spare it ("Trouble"); - Take it! - says the hostess, buttoning a shirt on her chest. - Crying. Must have jinxed ("I want to sleep"); - ... I do not need money, land, or sheep, and I do not need to be afraid of me and take off their hats when I go ("Steppe"); But he was persuaded, consoled and put in the carriage. The train started ("To Paris!"); - ... I all think that I am flattered because of the money. I do not believe anybody! I am heavy, brother, man, very heavy! ("Drunk"); A footman with whiskers proclaims toasts, and the music plays tush, Yefim Petrovich gets drunk completely and no longer recognizes anyone; it seems to him that he is not at home, but at a party, that he has been offended; in the hall he puts on a coat and a hat ... ("The Wedding"). Verbs generally refer to negative actions (fear, offend, offend, etc.). These actions are directed at an object - a person; actions related to inanimate objects do not have a negative coloration (burning the furnace).

7) Verbs of physiological action (17 units): eat, drink something, feed, give someone something to drink, breathe, etc. [Babenko, 1999, S. 435-443]. The following verbs are used as predicates: drank and ate / ate / drank (5), drank (2), sighed, began to dine, cough, began to drink, drank, etc. For example: They sighed, were horrified, drank a glass of tea and went to the outhouse ("Swedish match"); Mashenka straightened her hair, wiped herself with a wet towel and went into the dining room. They have already begun to dine there ... ("Trouble"); "We can drink and eat, but we don't remember business," he says. "Yesterday was all day long and we knew that we were drinking and eating, and I suppose they forgot to write down the expenses. What a memory, Lord! ("Cold blood"); While they ate, there was a general conversation ("Steppe"); - ... I signed with Likhodeev ... From him I went to Pelageya Emelyanovna ... Then they planted breakfast and drank coffee ("New Year's Great Martyrs"); They drink it (champagne) getting engaged and getting married, when for two or three illusions they take upon themselves heavy chains for life ("Champagne"); We started by drinking a large glass of vodka and eating oysters ("Drunk"); - Why, just pi ... we drank! ("Critic"). Chekhov, using the verbs of this group, describes the life of society: tea drinking and festivities with champagne are held in the circle of loved ones. The description of the feast for Chekhov is typical: the story "New Year's Great Martyrs" is dedicated to this, the heroes of which, visiting numerous relatives and friends and taking food and drinks everywhere, end up in the hospital.

8) Sound verbs (14 units): to publish, produce any sounds, noises not related to speech, using the vocal apparatus, when interacting, hitting any objects against each other or using any instruments [Babenko, 1999, S. 444-457].

The following verbs are used as predicates: they ring (5), rang (4), clapped / slammed (2), squeaked, rustled, squealed. For example: - It seems that they are calling somewhere, - says Anya, making big eyes. Everyone stops playing and, with open mouths, stares at the dark window. The reflection of the lamp flickers into the darkness. - It was heard. - At night they only call at the cemetery ... - says Andrey. - Why do they call there? ("Kids"); A loud, thick roar was heard: someone was clapping at someone, and this someone, probably a face with a tail instead of a nose, roared and laughed 
loudly that the locks on the suitcase trembled ("Kashtanka"); When the wagon train moved on, the bell rang in the church for mass ("Steppe"); In the second group they made a noise and pointed to the little bustard ("Petrov's Day"); They uncorked another bottle and rang the dishes. Someone strode, jingling spurs. They slammed the door. 34 ("Run into"); They say that at midnight they rang for matins, but we did not hear this ringing. ("Snack"). Out of 5 cases we observe the verb rang / rang (about bells), which shows the Christian tradition of the 19th century.

9) Verbs of object placement (12 units): place / place, place / be placed in any place or penetrate somewhere, moving, moving and making any efforts; include, attaching as an additional component; close / open, creating a closed space, isolation, an obstacle for vision, access to someone or inside something [Babenko, 1999, pp. 607-637]. The following verbs are used as predicates: planted (3), bury / buried (2), uncorked (2), hung, put, unlocked, put, opened. For example: The walls were gray, the ceiling and cornices were smoked, there were cracks on the floor and holes of unknown origin were gaping (it was thought that the same strongman had punched them with his heel), and it seemed that if a dozen lamps were hung in the room, it would not stop be dark ("Steppe"); And after the death of the rich Fyodor, they will not bury them in gold, not in diamonds, but in the same black earth as the last poor man ("The shoemaker and the evil spirits"); And there, just at that time, the sleepers and rails were being laid ("Lights"); The piggy bank, in which the governess hid dimes and old stamps, was unlocked. They unlocked it, but failed to lock it, although they scratched the entire lock ("Trouble"); And he was sad, very sad! They put him to sleep on the chest and warned him that if he wanted to eat at night, he should go out into the corridor and take a chicken covered with a plate at the window ("Steppe"); - I signed with Likhodeev ... From him I went to Pelageya Emelyanovna .. Then they planted breakfast and drank coffee ("New Year's Great Martyrs"); Dasha, hearing that the cupboard was opened without her permission, perked up ... ("Carelessness"); They uncorked another bottle and rang the dishes. Someone strode, jingling spurs. The door was slammed ("I ran into it"). These sentences use verbs whose action is directed at an animate object (planted, laid down) and at an inanimate object (uncorked, opened, laid down, hung up).

10) Verbs of interpersonal relations (12 units): to relate to someone in any way, showing any feelings; show an attitude towards someone with gestures, facial expressions, sounds, movements or any other actions; agree with someone about something, come to a common opinion, a mutual agreement; to win over someone with something [Babenko, 1999, pp. 588-606]. For example: This is not love, he told himself. - they don't fall in love with those who are thirty and married ... It's just a little affair ... Yes, an affair ... ("Volodya"); ... Your pride was offended, and now you were crying, you are going to leave, but I also have pride, and you do not spare it ("Trouble"); They loved me, happiness was close and, it seemed, lived shoulder to shoulder with me; I lived happily ever after, not trying to understand myself, not knowing what I expect and what I want from life, and time went on and on ... ("The story of Mrs. NN"); - ... I all think that I am flattered because of the money. I do not believe anybody! I am heavy, brother, man, very heavy! ("Drunk"); ... I was insulted, humiliated ... and I was insulted in my life ("Champagne"); - They don't say anything, and so ... they despise ("The Tenant"). The verbs insulted, humiliated, we considered it possible to include in this group as well (cf. group 6 the verbs of the qualitative state). On the one hand, the object experiences a change in the quality of the state, on the other, the action takes place between individuals. The verbs of this group designate feelings and their manifestations: love, dislike, distrust. 
11) Verbs of social relations (11 units): to win, overcoming resistance, difficulties, to win in a struggle, competition, etc., as well as to be defeated in something; make someone do something, influence, influence, persuade, proving, giving reasons, arguments, inciting to any decision, opinion; subjugate, making them dependent [Babenko, 1999, pp. 607-637]. The following verbs are used as predicates: they will drive away (4), ordered, awarded, punished, held, seduced, convinced, did not let in. For example: Avdeev was ordered to get up and walk ("Trouble"); By two o'clock a lot had been done: two were sentenced to prison companies, one privileged one was deprived of his rights and sentenced to prison, one was acquitted, one case was postponed ("In court"); They say that later they found human bones in the basement. Bones ... They, therefore, robbed the people, and then buried them so that there were no traces. Well, then they were punished in Morshansk through executioners ("Steppe"); Three pairs of oxen and two workers are holding ("Steppe"); They also led the waiters astray from the path of truth, forcing them to drink to fraternite ... ("A story that has a hard time finding a name"); - Headphone, whisper ... Do you think that Yegorka Kornyushkin was not driven through me? ("A Conversation of a Man with a Dog"); But he was persuaded, consoled and put in the carriage. The train started ("To Paris!"); Apart from them and the lackeys at the door, there was not a soul in the hall: on Frolov's order, no one was allowed in ("The Drunken").

12) Verbs of motion (10 units): to move in a certain direction from anywhere on a solid surface or liquid, air [Babenko, 1999, pp. 27-70]. The following verbs are used as predicates: went (2), did not pass, walked, arrived, began to run, avoided, were late, drove, came. For example: We haven't traveled ten miles yet, but he was already thinking: "It's time to rest!" ("Steppe"); We went into the garden, where the bedroom window looked out. ("Swedish match"); They sighed, were horrified, drank a glass of tea and went to the outhouse. ("Swedish match"); Probably, they walked barefoot on the roof, because the iron grumbled dully. ("Steppe"); The owners see that they have come for the merchant, they were frightened and, God forbid, their feet ... But we rather went to the yard, harnessed and - and only saw us ... ("Steppe"); They began to run around the village and look, avoiding all the taverns and huts, but they did not find him. ("In a court"); Too late ... ("Cold Blood"); From the "Arcadia" we went to the Krestovsky Garden. ("Crow"); - Well, thank the creator, they came ... - says Kozyavkin, taking a breath. "In our position, walking five versts from the station with infantry is a feat. I was terribly worn out! And, as luck would have it, not a single cab driver ... ("The Lost Ones").

13) Verbs of social activity ( 9 units): to achieve / achieve a set goal or any results, striving for something and making efforts; to disseminate something, making it known, making it public, publishing, publishing in print and using the media, discovering, manifesting, showing to many or transmitting in verbal form any information; perform any piece of music, sing, dance or play a musical instrument, read any literary text aloud [Babenko, 1999, pp. 375-434]. The following verbs are used as predicates: equalized (3), did not, they took fashion, gave a masquerade ball, danced, took, got along. For example: Never before had such violence been committed against her, never had she been so deeply insulted as now ... ("Trouble"); - Look what fashion they took ... ("Cold Blood"); In the X-th public club with a charitable purpose they gave a masquerade ball, or, as the local young ladies called it, a ball-pair ("Mask"); - Ti-ishe! I wish to dance! You must respect my character! Kachucha! Kachucha! ("Crow"); With the general guilty military ... - Filenkov muttered, - 38 when even ... professors are taken as soldiers ... when everyone has been equalized ... and even the freedom of publicity ... ("Crow"). Predicate verbs, in most cases, describe actions along the way, that is, they do not have much value for 
revealing the characters of the heroes. The exceptions are the sentences: With modern education, everyone was equalized ("Crow") and - I, your honor, feel my guilt, but ... if you take that with general guilt ... military universality, everyone was equalized, and how am I, after all, an educated person , I can't exist at Mamzel Barb's birthday party in the form of a lower rank, then I put on this suit for my household, as I am, therefore, a hereditary honorary citizen ("The Crow"). The hero Filenkov, explaining himself to Lieutenant Strekachev, repeatedly uses the word equalized, as if relieving himself of responsibility for wearing a uniform that does not correspond to his rank.

14) Verbs of creative activity (6 units): to make, produce, do something with the help of tools, applying physical effort; create, produce something as a result of labor, creatively working on something; prepare food, drink in any way, bringing food products to a ready-to-eat state; inform someone of information in written or printed form [Babenko, 1999, pp. 265-302]. The following verbs are used as predicates: typed, write, mold, printed, composed, fried. For example: They printed about me! ("Joy"); Then the old man, angrily shaking his hands, described horse stadiums, bullfights, theaters, workshops of artists, where naked women are painted and molded from clay ("Without a title"); - Can not! - announced Pochechuev, grabbing his hair. - How will it seem to you? For a month, for a whole month, they were typing in arshin letters that we would have Porcupines, they bragged, broke down, took away the subscription money, and suddenly such a meanness! BUT? Yes, for this it is necessary to hang! ("Remedy for 39 hard drinking"); - ... And in the tavern Vasya glass after glass, glass after glass ... "You, screaming, you are taking me to death!" He began to make noise ... And as after the vodka he began to drink sherry, then ... the protocol was drawn up ("To Paris!"); - And at that time, as on purpose, we ate grated radish with kvass and fried fish, and there was such a stench in the apartment that the devil was sick of it ("Father"). For Chekhov, creative work is aimed at making paper products (documents, articles in newspapers), art products.

15) Verbs of being (4 units): to give rise to any event, phenomenon, etc., to contribute to the appearance, emergence of someone (something); to begin its existence, to appear somewhere, to be explicit, acting, etc. [Babenko, 1999, S. 445-481]. The following verbs are used as predicates: did not wait, finished, quieted down, started. For example: "We didn't wait!" - I thought ("Lights"); The merchants were cut so that there was no living space left on the body; finished their business and dragged both of them out of the way, father to one side, and son to the other ("Steppe"); I spat, jumped up and knocked on the wall. The next room was quiet. I closed my eyes again. Goose bumps, fur, cotton wool ran in ... But - alas! - a minute later they yelled again ("I ran into it"); We started by drinking a large glass of vodka and eating oysters ("Drunk"). We received 15 semantic groups of verbs, according to which we were allocated, highlighted in the stories of A.P. Chekhov. I would like to note that during the analysis of the stories, we did not find any verbs with the meaning of relationship. Relationship verbs L.G. Babenko names those that mean "to be in a mutual connection, to lead to the interconnection of actions, phenomena, objects, deeds, etc.": to avoid, reflect, replenish, pay, reduce, etc. [Babenko, 1999, S. 556-563].

Actively A.P. Chekhov uses sentences in which the verb of speaking is used. It serves as an introductory word, but semantically it is very important and closely related to the main meaning of the verb. Stylistically, this introductory word is considered colloquial. 


\section{References:}

1. Mirziyoyev Sh. Oliy ta'limda foydalaniladigan nashrlar va axborotlarni uzatishning zamonaviy manbalari. 19 май 2018 й.

2. Akramova Gulbahor Renatovna, Akramova Surayo Renatovna. Pedagogical and psychological conditions of preparing students for social relations on the basis of the development of critical thinking. Psychology and education. Vol. 58 No. 2 (2021): Volume 58 No. 2 (2021). P. 48894902 http://psychologyandeducation.net/pae/index.php/pae/article/view/2886

3. Aminova Feruza Hayitovna. Axiological analysis of socio-aesthetic problems in hadiths An International Multidisciplinary Research Journal 1457-1462, 2020. https://www.indianjournals.com/ijor.aspx ?target=ijor:aca\&volume=10\&issue=5\&article=212

4. Aminova Feruza Hayitovna. Основные принципы исследовательского обучения в школе 2018 international scientific review of the problems of pedagogy and psychology 19 aprel 2018 https://scientific-conference.com/images/PDF/2018/1/basic-principles.pdf

5. Amonov Ulugmurod Sultonovich. Abdurauf Fitrat is one of the earliest researchers of uzbek folklore. "Academicia” An International Multidisciplinary Research Journal, India. June 2020. 669-673 p. 10.5958/2249-7137.2020.00616.3 https://www.indianjournals.com/ijor.aspx $?$ target=ijor:aca \&volume $=10 \&$ issue $=6 \&$ article $=096$

6. Amonov Ulugmurod Sultonovich. Folklore in the works of Abdurauf Fitrat. International scientific journal «Theoretical \& Applied Science», USA. September 30, 2016. 12-15 p. https://www.semanticscholar.org/paper/folklore-in-the-works-of-abdurauf-fitrat amonov/dcc79abce08ba4602c2dc5b5ae3a87b345797d63

7. BuryakovYu.F. The history of non-ferrous metals in Uzbekistan in antiquity and in the Middle Ages. // Materials of the Republican Scientific and Practical Conference. NEVELLAND. - C11.

8. CM: Kuchersky N.I, Astanzaturian G.G. BerdnikovE.A.Navoi. CGA RUZ. F - M 20, OP. 16, units. XP.62, 1. 19. Norma.uz National Database of Legislation, 06.03.2020, No. 07/20/4629/0258)

9. Eshonkulova Dilafruz Husenkizi. Ways to develop critical thinking in adolescents An International Multidisciplinary Research Journal184-188 2020, https://www.indianjournals.com/ijor.aspx ?target=ijor:aca\&volume=10\&issue=10\&article=024

10. Жумаева Ф Р. Использование разных видов текстов в качестве дидактического материала на уроках русского языка. https://cyberleninka.ru/article/n/ispolzovanie-raznyh-vidov-tekstovv-kachestve-didakticheskogo-materiala-na-urokah-russkogo-yazyka

11. Жумаева Ф. Р., Хакимова Н. Х. Формирование языковой и коммуникативной компетенции учащихся при работе над http://eclss.org/publicationsfordoi/istanbulonline.pdf\#page $=168$

12. Ruziyevna J. F, Baxronovna M. F. Tolerance is the basis for creating a humanistic culture in the world. Academicia: An International Multidisciplinary, 2020. https://www.indianjournals.com/ijor.aspx ?target=ijor:aca\&volume=10\&issue=5\&article=254

13. Khodjieva Farogat Oltievna The Actuality And The Content of Forming Critical Thinking Skills Of Primary School Pupils Psychology and Education Journal 2020. http://psychologyandeducation.net/pae/index.php/pae/article/view/986 
14. Muradova Dilfuza Zhurakulovna. 58-60 2020 The formation of communicative competence of pupils primary school. European Science58-60 $2020 \mathrm{https} / / / \mathrm{scientific}-$ publication.com/images/pdf/2020/52/european-science-3-52-.pdf

15. Rasulov Jasur Saparovich Effects of training based on neuropedagogy International Scientific Review of the Problems and Prospects of Modern Science and Education 30.08.2018 https://scientific-conference.com/h/sborniki/pedagogicheskie-nauki2/1376-effektyobucheniya.html

16. RizaevS.NavoiyGorno-Metallurgical. - Tashkent: Shark, 2008.- C. 86.

17. Ryziqulova Amina Totliboyevna. The role of national values in ensuring the stability of marriage and family relations in modern uzbek families. ACADEMICIA: An International Multidisciplinary Research Journal 88-93 $2020 \quad$ 10.5958/2249-7137.2020.01126.X. https://saarj.com/wp-content/uploads/ACADEMICIA-OCTOBER-2020-FULL-JOURNAL.pdf.

18. Sattorovna Jamilova Bashorat, Sadriddinovna Nuriddinova Shaxnoza The spiritual description of adults in uzbek children's prose-the place of literary psychologism. Academicia: an international multidisciplinary research journal. Year: 2021, Volume:11, Issue:1

19. See: Batalova I. Gaev Y. Combine, time, fate. Tashkent. Abu Ali Ibn Sina Medical Literature Sina Ali. - C. 57.

20. Shalatonin B.S. "Shadows on the rocks" - T: A. Kadyri, 1999. - C.20.

21. Shamsutdinov R., Мўминов Н.ўзбекистонTarios. -T.: Sharc; 2013. -b. 25.

22. Temirov, Odinaeva Z. CadimgiDipboard Con-metallurgy Tarios. - T.: Yanga ASR Avlodi, 2008. - B.8.

23. Temirov, Odinaeva Z. CadimgiDipboardKon-Metallurgy Tarios. - T.: Yangang ASR Avlodi, 2008. -B. 15

24. Tukmuradova Malika Elmurodovna. Impact of digital education on delivering English lessons An International Multidisciplinary Research Journal1787-1791,2020 https://www.indianjournals.com/ijor.aspx?target=ijor:aca\&volume=10\&issue=11\&article=289

25. Usmanov K. The history of Uzbekistan. - T: "Shark", 2007. - p.64.

26. Xalilova Ruxsora Raupovna. The Formation Of Professional Speech Of Students In The Learning Process At The University. European Journal of Research and Reflection in Educational Sciences Vol 7. 2019 http://www.idpublications.org/wpcontent/uploads/2019/09/Full-Paper-THE-FORMATION-OF-PROFESSIONAL-SPEECH-OFSTUDENTS-IN-THE-LEARNING-PROCESS-AT-THE-UNIVERSITY.pdf

27. Абилова Гаухар Оринбековна. On the issue of training highly qualified teachers. International Scientific Review of the Problems and Prospects of Modern Science and Education. 2018 https://scientific-conference.com/h/sborniki/pedagogicheskie-nauki2/952-on-the-issue.html

28. Ахатова Дурдона Актамовна. Didactic Opportunities to Ensure Compliance With The Goal And Content Of Education in The Modernization Process International Scientific Review of the Problems and Prospects of Modern Science and Education12 dekabr 2019 yil https://scientific-conference.com/h/sborniki/pedagogicheskie-nauki2/2071-didakticheskievozmozhnosti.html

29. Ахатова X. А. 2019. Факторы повышения эффективности воспитания гармоничного поколения в образовании International Scientific Review of the Problems and Prospects of 
Modern Science and Education 12 dekabr 2019 yil. https://scientificconference.com/h/sborniki/pedagogicheskie-nauki2/2070-faktory-povysheniyaeffektivnosti.html

30. Баходир Маъмуров. Акмеологик Ёндашув Асосида Бўлажак Ўқитувчиларда Таълим Жараёнини Лойихалаш Кўникмаларини Ривожлантириш. Том 1 № 1 (2020): Таълим ва инновацион тадқиқотлар. http://interscience.uz/index.php/home/article/view/15

31. Башорат Жамилова, Мохигул Каххорова. Болалар детектив насридаўсмирлар рухияти тасвири. Том 1 № 1 (2020): Таълим ва инновацион тадқиқотлар. http://interscience.uz/index.php/home/article/view/37

32. Лукмонова С.Г. Цифровые образовательные ресурсы в педагогической деятельности [Digital educational resources in teaching] // XXI International scientific review of the problems of philosophy, psychology and pedagogy. https://scientificconference.com/h/sborniki/yuridicheskie-nauki2/2249-media-security-trend.html

33. Махмудов Мэлс. Дидактик Лойихалаш - Замонавий Таълимда Самарадорлик Кафолати. $\begin{array}{llllll}\text { Том } & 1 & \text { № } & 1 & \text { (2020): }\end{array}$ http://interscience.uz/index.php/home/article/view/14

34. Рўзиева М. Ё. Туркий халқлар фольклорида ранг ифодаловчи сўзлар ва уларнинг семиотик тахлили. Том 1 № 1 (2020): Таълим ва инновацион тадқиқотлар. http://interscience.uz/index.php/home/article/view/34

35. Эльчиева Динара Толубаевна . Формирование познавательного интереса и познавательной активности младших школьников European Science50, 2020 June. https://scientific-publication.com/images/PDF/2020/53/EUROPEAN-SCIENCE-4-53-.pdf 